\title{
Multivariate analysis of soil heavy metal pollution and landscape pattern in Changhua county in Taiwan
}

\author{
Yu-Pin Lin ${ }^{\mathrm{a}, *}$, Tung-Po Teng ${ }^{\mathrm{b}}$, Tsun-Kuo Chang ${ }^{\mathrm{c}}$ \\ a Department of Landscape Architecture, Chinese Culture University, 55 Hwa-Ken Road, Yangming Shan, Taipei 111, Taiwan \\ ${ }^{\mathrm{b}}$ Department of Geography, Chinese Culture University, 55 Hwa-Ken Road, Yangming Shan, Taipei 111, Taiwan \\ ${ }^{\mathrm{c}}$ Graduate Institute of Bioenvironmental Systems Engineering, National Taiwan University, 1 Sec. 4 Roosevelt Road, Taipei 106, Taiwan
}

Received 12 June 2001; received in revised form 30 April 2002; accepted 1 May 2002

\begin{abstract}
This study applied factor analysis and landscape indices of 55 sampling sites in Changhua county in Taiwan to characterize the factor patterns of eight soil heavy metals ( $\mathrm{As}, \mathrm{Cd}, \mathrm{Cr}, \mathrm{Cu}, \mathrm{Hg}, \mathrm{Ni}, \mathrm{Pb}$ and $\mathrm{Zn}$ ) and the interrelation patterns of these soil heavy metals, landscape and human activities. The landscape analysis results indicated that landscape indices can elucidate spatial landscape patterns, urbanization and industrialization, demonstrating that higher landscape diversity corresponded to a higher ratio of urban planning area to the number of industrial plants. Factor analyses revealed that soil heavy metals and data concerning landscape data could be grouped into a six-factor model that accounts for $82 \%$ of all the variation of data. Moreover, the first factor included the concentration of $\mathrm{Cd}, \mathrm{Cr}, \mathrm{Cu}, \mathrm{Ni}$ and $\mathrm{Zn}$, and urbanization and industrialization landscape indices. These variables together explained $34.5 \%$ of the variation in the concentration of the soil heavy metals and landscape indices data of this study area. Local urbanization and industrialization caused local soil pollution by heavy metals on the selected sampling sites in Changhua county in Taiwan. Geographic information system can fully display the spatial patterns and relationships among landscape indices and concentration of soil heavy metals in this study area.
\end{abstract}

(C) 2002 Elsevier Science B.V. All rights reserved.

Keywords: Landscape patterns; Landscape indices; Soil pollution; Urbanization; Geographic information system

\section{Introduction}

A landscape pattern is a mixture of natural and human-managed patches that vary in size, shape, and arrangement, and result from complex interactions of physical, biological, and social forces (Burgess and Sharpe, 1981; Forman and Godron, 1986; Krummel et al., 1987; Turner, 1987, 1990; Hulshoff, 1995). Agricultural landscapes reflect not only natural constraints, but also financial resources and social con-

\footnotetext{
* Corresponding author. Tel.: +886-2-2862-6433; fax: +886-2-2861-7507.

E-mail address: yplin@staff.pccu.edu.tw (Y.-P. Lin).
}

ditions (Forman and Godron, 1986; Urban et al., 1987; Fu and Chen, 2000). Human activities greatly shape landscapes, creating a mosaic of natural and human-managed patches that vary in size, shape, and arrangement (Burgess and Sharpe, 1981; Forman and Godron, 1986; Krummel et al., 1987; Leduc et al., 1994). Such activities also cause pollution. For instance, urban areas disperse pollution, humans, information, products, and in some cases heat, throughout suburbia (Forman, 1995). Moreover, urban, suburban and agricultural areas may interact with each other. Control of the diffusion of pollution (Haycock and Muscutt, 1995), and characterizing, understanding and managing landscape patterns and structures are 
major issues that affect agricultural landscapes and suburban areas. Accordingly, a full delineation of landscape and pollution patterns may improve the efficiency of environmental management and agricultural, suburban and urban planning.

Landscape indices such as patch size, patch shape index (curvature), landscape diversity $(H)$, dominance $(D)$, and fractal dimension (FD), have been widely used to elucidate landscape patterns and interactions. See, for example, Hulshoff (1995), Haines-Young and Chopping (1996), Li and Archer (1997), Johnson and Gage (1997), Obeysekera and Rutchey (1997), Bastian and Roder (1998), Aguiar and Sala (1999), Hietala-Koivu (1999), Hokit et al. (1999), Nikora et al. (1999), Stadler (1999), Baudry et al. (2000), Klenner et al. (2000) and Weinstoerffer and Girardin (2000). Patch size directly describes the landscape pattern. Dominance measures the extent to which one or a few legend types dominate the landscape (O'Neill et al., 1988; Hulshoff, 1995). Fractal dimension can be used to estimate the complexity of the geometry of land use (Kienast, 1993).

Multivariate analysis offers techniques for classifying relationships among measured variables. The two most common multivariate analyses are principal components analysis and factor analysis. Notable examples of their use in environmental chemistry are found in the work of Briz-Kishore and Murali (1992), Subbarao et al. (1996), Jayakumar and Siraz (1997), Meng and Suffet (1997), Brejda (1998) and Carlon et al. (2001). Factor analysis is based on the fundamental assumption that some underlying factors, fewer than the number of observed variables, are responsible for the covariation of the observed variables (Lewis-Beck, 1994). Principal component analysis, a statistical technique, linearly transforms an original set of variables into a substantially smaller set of uncorrelated new variables that represent most of the information of the original data set (Lewis-Beck, 1994). A small set of uncorrelated variables is much easier to understand and use in further analysis than a larger set of correlated variables (Lewis-Beck, 1994).

Industrialization and urbanization in Taiwan have polluted some agricultural soils by discharging wastewater into irrigation ditches. In 1983, the Environmental Protection Administration (EPA) of Taiwan began a collaborative research program to identify the presence of $\mathrm{As}, \mathrm{Cd}, \mathrm{Cu}, \mathrm{Cr}, \mathrm{Hg}, \mathrm{Ni}, \mathrm{Pb}$ and $\mathrm{Zn}$ in soils. The program also aimed to detect additional soil properties, such as cation-exchange capacity and $\mathrm{pH}$. These studies sampled soils from 878 sites that were representative of agricultural areas in Taiwan.

Our study applied factor analysis and landscape indices (including landscape diversity, landscape dominance, fractal dimension, the density of irrigation ditches and the number of industrial plants) of 55 sampling sites in Taiwan's Changhua county, to characterize both factor patterns of eight soil heavy metals (As, $\mathrm{Cd}, \mathrm{Cr}, \mathrm{Cu}, \mathrm{Hg}, \mathrm{Ni}, \mathrm{Pb}$ and $\mathrm{Zn}$ ) and the landscape. Correlations between the factor patterns and the landscape indices were analyzed to elucidate the characteristics of both the heavy metal pollution of the soil, and the urbanization at these 55 sampling sites. Factor analysis was also applied to group soil heavy metals and landscape indices and thereby delineate the interrelationships between soil heavy metals, landscape and anthropogenic activities.

\section{Materials and methods}

Our study uses data obtained by the EPA between 1981 and 1997. Samples were taken from geographically distributed sites in a network formation. Topsoil was sampled at depths of $0-15 \mathrm{~cm}$. The EPA classifies the concentrations of soil heavy metals into five classes (Table 1). Table 1 shows that the concentrations of soil heavy metal samples in the first and second classes are considered to represent no soil heavy metal pollution. The concentrations of soil heavy metals in the third class are defined as background values. The

Table 1

Soil heavy metal class in Taiwan

\begin{tabular}{llllll}
\hline $\begin{array}{l}\text { Soil heavy } \\
\text { metals }\end{array}$ & 1 & 2 & 3 & 4 & 5 \\
\hline $\mathrm{As}^{* *}$ & & $<4$ & $4-9$ & $10-60$ & $>60$ \\
$\mathrm{Cd}^{*}$ & & $<0.05$ & $0.05-0.39$ & $0.40-10$ & $>10$ \\
$\mathrm{Cr}^{*}$ & & $<0.10$ & $0.10-10$ & $11-16$ & $>16$ \\
$\mathrm{Cu}^{*}$ & $<1$ & $1-11$ & $12-20$ & $21-100$ & $>100$ \\
$\mathrm{Hg}^{* *}$ & & $<0.10$ & $0.10-0.39$ & $0.40-20$ & $>20$ \\
$\mathrm{Ni}^{*}$ & & $<2$ & $2-10$ & $11-100$ & $>100$ \\
$\mathrm{~Pb}^{*}$ & & $<1$ & $1-15$ & $16-120$ & $>120$ \\
$\mathrm{Zn}^{*}$ & $<1.5$ & $1.5-10$ & $11-25$ & $26-80$ & $>80$ \\
\hline
\end{tabular}

Unit: $\mathrm{mg} / \mathrm{kg}$.

${ }^{*} 0.1 \mathrm{~N} \mathrm{HCl}$ extractable content.

** Total content. 


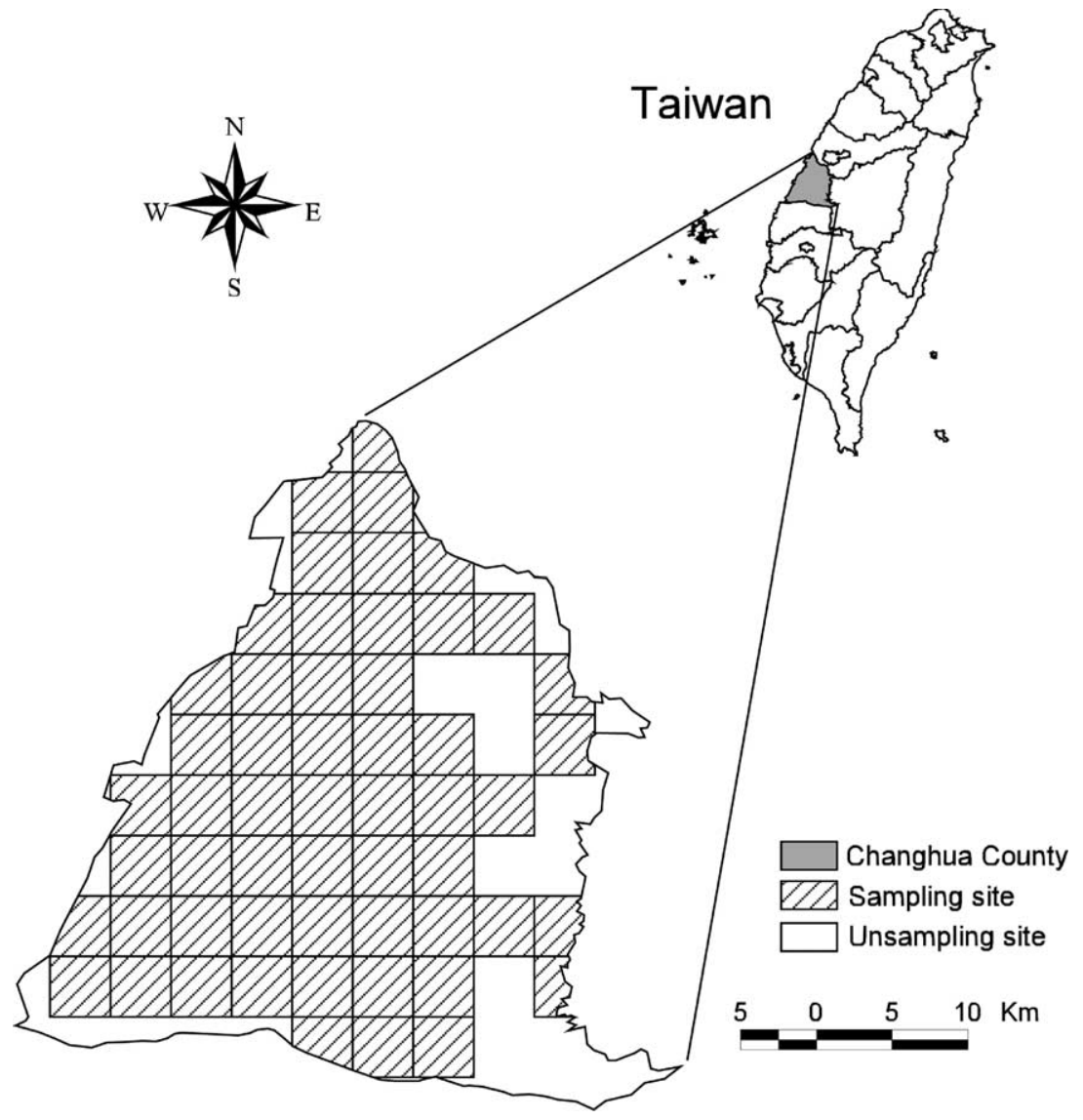

Fig. 1. Study area and sampling sites.

fourth and fifth soil heavy metal classes require intensive monitoring and consideration of remedial action. Taiwan EPA has also supported investigation projects for detail monitoring and remediation of soil heavy metals in 2002.

Fifty-five sampling sites within Changhua county (Fig. 1), located in the center of Taiwan were selected from the original 878 sampling sites across Taiwan, and considered in this study. Changhua county is one of the most important agricultural counties in Taiwan. In this county, some local sites might be polluted by wastewater of industrial plants that has been distributed through irrigation systems. Lin and Chang (2000a,b) and Lin et al. (2001) indicated that the local spatial patterns of soil heavy metal pollution were significantly related to the locations of industrial plants and irrigation systems, in a $2.69 \mathrm{~km}^{2}$ site in northern Changhua county. Table 2 lists heavy metals that might be discharged with wastewater from different industrial plants.

The following landscape indices for each sampling site were used to characterize landscape patterns; landscape diversity $(H)$, dominance $(D)$, area-perimeter fractal dimension (FD), density of irrigation ditches (DL), number of electroplating plants (NE), number of textile plants (NT), number of livestock plants (NL), number of metal surface treatment plants (NMs) and number of metal plants (NM), total number of industrial plants $(\mathrm{Np})$ and the ratio of urban planning area (RAup). Fig. 2 shows land use data, as digitized and developed by the Food and Agriculture Department of the Council of Agriculture and the Department of Land Administration of the Ministry of the Interior in 1994. The land use data of the 55 sampling sites 
Table 2

Industrial plants and heavy metals

\begin{tabular}{ll}
\hline Element & Description of use \\
\hline $\mathrm{As}$ & Pesticides, pigments, glass, textiles, wood preservatives, fireworks, printing, tanning, enamels, ceramics, lubricating \\
& oil, alloys, oil cloth, linoleum, semiconductors, photo-conductors. \\
$\mathrm{Cd}$ & Electroplating, pigments, alloys, enamels, batteries, rubber, plastics, fungicides, motor oil, textiles. \\
$\mathrm{Cr}$ & Pigments, chrome tanning, electroplating, chrome-plating, corrosion inhibitor, varnishes, dye fixers, photography \\
& emulsion, defoliant. \\
$\mathrm{Cu}$ & Brass, dyes, wires, fungicides, alloys, plating, pipes, roofing, paints. \\
$\mathrm{Pb}$ & Batteries, paints, glass, insecticides, gasoline additive, ammunition, solder, brass and bronze, pigments. \\
$\mathrm{Hg}$ & Paints, catalyst, fungicides, pharmaceutical, plastics, paper products, batteries, electrical apparatus manufacturing. \\
$\mathrm{Ni}$ & Steel and alloys, pigments, cosmetics, batteries, electroplating. \\
$\mathrm{Zn}$ & Alloys, metal coating, ink, copying paper, cosmetics, paints, rubber, linoleum, glass \\
\hline
\end{tabular}

were clipped using Arcview 3.0a, to calculate landscape indices. The landscape diversity index $(H)$ was the Shannon-Weaver Diversity,

$H=-\sum_{i=1}^{m} P_{i} \log _{2} P_{i}$

where $P_{i}$ is the proportion of landscape type $i$ in a site, and $m$ is the number of observed landscape types.

Dominance $(D)$ is given by,

$D=\ln c+\sum_{k=1}^{c} P_{k} \ln P_{k}$

where $c$ is the number of land use types and $P_{k}$ is the proportion of area in type $k$.

For all landscape types at each sampling site, the FD were estimated by linear regression using,

$P=C A^{\mathrm{FD} / 2}$

where $P$ is the perimeter of a patch; $A$ is the area of a patch, and $C$ is a constant.

The DL was defined as,

$\mathrm{DL}=\frac{\mathrm{TL}}{S}$

where TL is the total length of irrigation ditches at each sampling site, and $S$ is the area of the sampling site. TL was extracted and calculated using the geographic information system, ArcView 3.0.

The ratio of the urban planning area to the area of the sampling site is defined as,

RAup $=\frac{\text { Aup }}{S}$ where Aup is the urban planning area at each sampling site.

NE, NT, NL, NMs, NM and Np are the number of electroplating, textile, livestock, metal surface treatment, metal, and all industrial plants at each sampling site, respectively.

Landscape indices, including landscape diversity $(H)$, landscape dominance $(D)$, area-perimeter fractal dimension (FD), density of irrigation ditches (DL), urban planning area ratio (Raup) and the number of industrial plants (electroplating industry (NE), textile industry (NT), livestock industry (NL), metal surface treatment industry (NMs) and metal industry $(\mathrm{NM})$ ), the total number of industrial plants $(\mathrm{Np})$, were extracted and calculated using the geographic information system, ArcView 3.0a.

Fig. 3(a) shows the urban planning area in the study area, as digitized by the Construction and Planning Administration of Ministry of the Interior. Fig. 3(b) and (c) depict the irrigation system and location of industrial plants. The nine land-use types-agricultural (75.4\%), built-up (10.4\%), hydraulic $(9.7 \%)$, industrial $(2.1 \%)$, recreational $(0.3 \%)$, traffic $(0.3 \%)$, mining $(<0.1 \%)$, military land-use $(<0.1 \%)$, and others (2.1\%) were defined by the Department of Land Administration of the Ministry of the Interior and were used to calculate landscape diversity.

The factor analyses were performed by computing eigenvalues and eigenvectors of the data, using principal components methods and the statistical software, SPSS (Norusis, 1993). Factors with eigenvalues higher than one were retained. The first factor explains the most variation in interesting variables, the second factor the next highest variance, and so on (Carlon et al., 


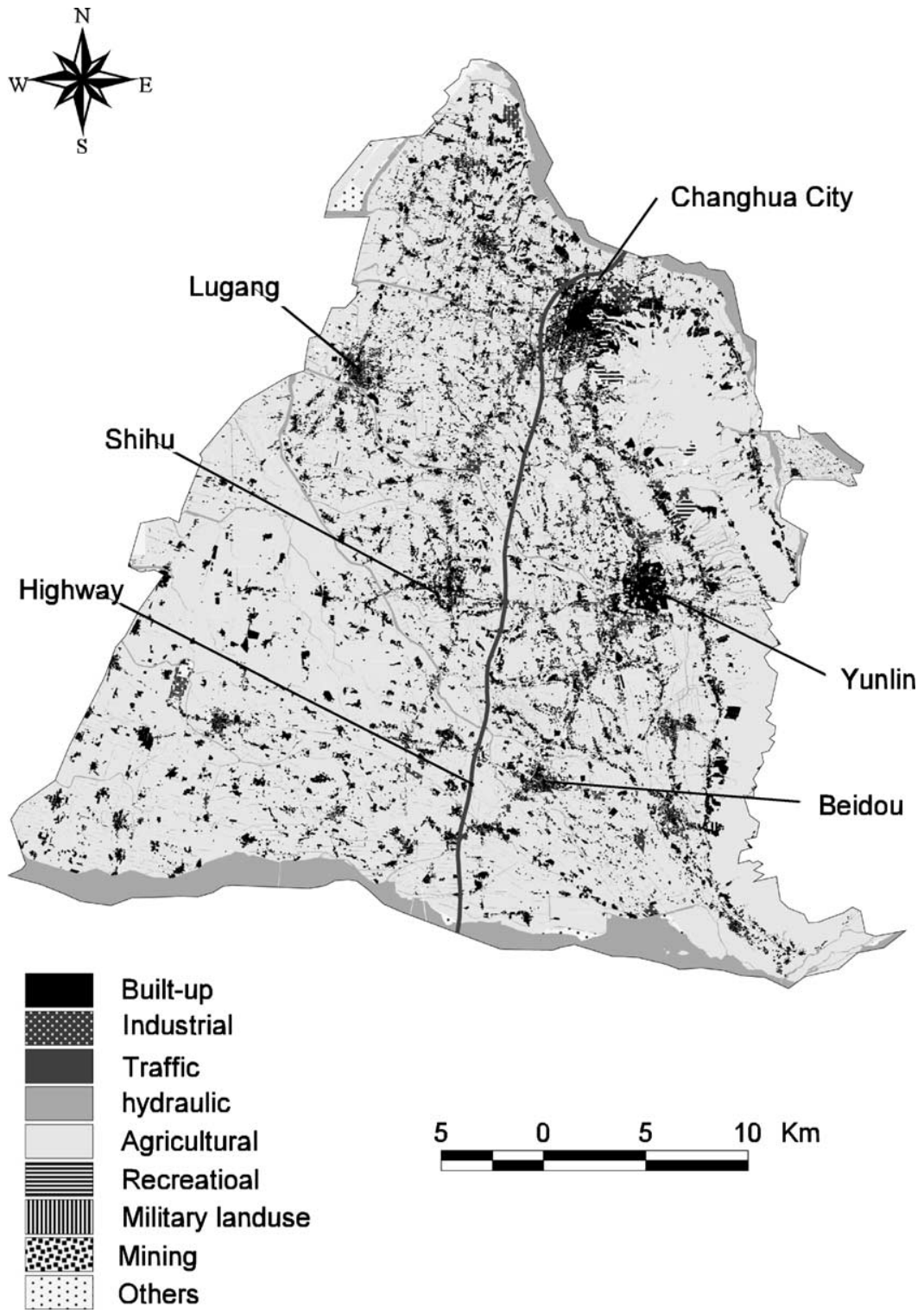

Fig. 2. Land use of Changhua county.

2001). Finally, the factor scores are calculated from variables, using regression methods with a matrix of factor-score coefficients. In this study, factor analysis was first applied to determine the factor patterns of eight soil heavy metals ( $\mathrm{As}, \mathrm{Cd}, \mathrm{Cr}, \mathrm{Cu}, \mathrm{Hg}, \mathrm{Ni}, \mathrm{Pb}$ and $\mathrm{Zn}$ ) at these 55 sampling sites. Moreover, these eight soil heavy metals and landscape indices were grouped by factor analysis to delineate interrelationships between soil heavy metals and the landscape. Figs. 4 and 5 show spatial maps of the measured values for these heavy metals. Table 3 summarizes the basic statistics of the investigated heavy metals. Figs. 6 and 7 show landscape indices at the 55 sampling sites. 


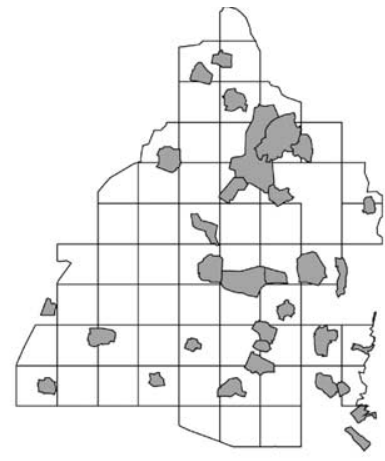

(a)

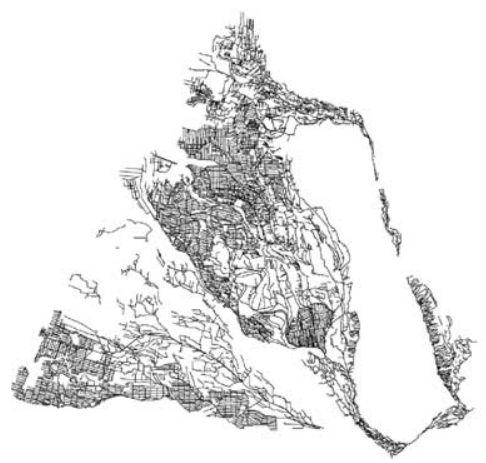

(b)

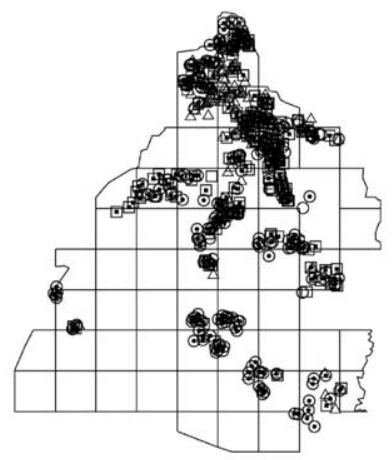

(c)
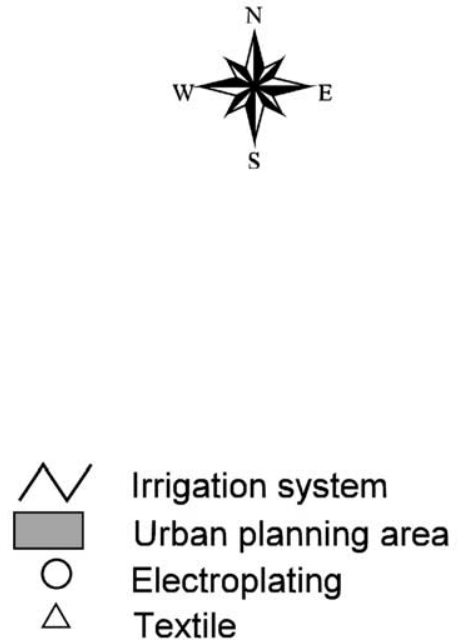

$\odot \quad$ Livestock

$\square \quad$ Metal surface treatment

घetal

Sampling site

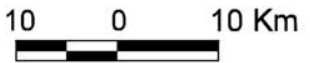

Fig. 3. Spatial distribution of: (a) irrigation system, (b) urban planning area, and (c) industrial plants.

\section{Results and discussions}

\subsection{Landscape indices}

The sampling sites with high landscape diversity were in the east of Changhua county (Fig. 6(a)). High landscape dominance sites were in the southwest of Changhua county (Fig. 6(b)). A comparison of the urban planning area and landscape diversity maps (Figs. 3(a) and 6(a)) shows that urbanization dominated the landscape diversity. Moreover, the spatial distribution of landscape diversity values seems to 


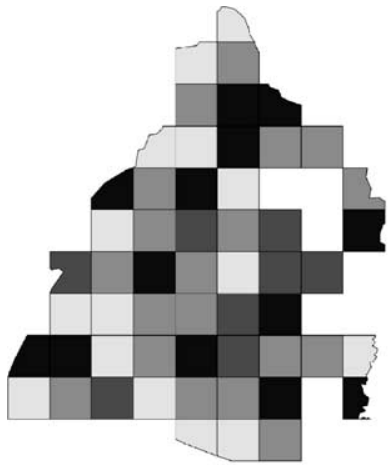

(a)

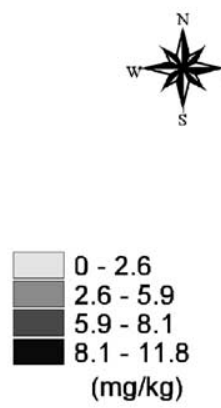

(mg/kg)

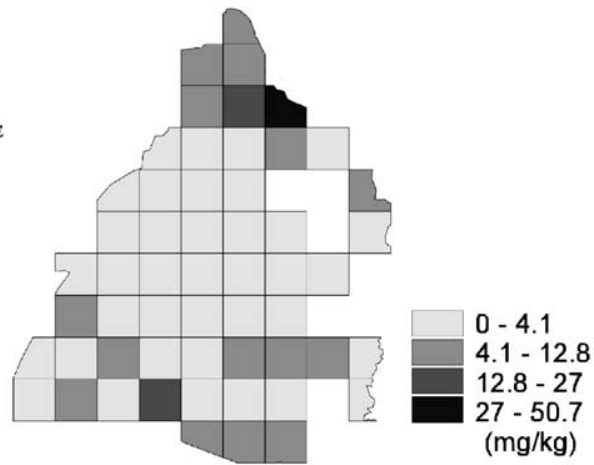

(c) (b)

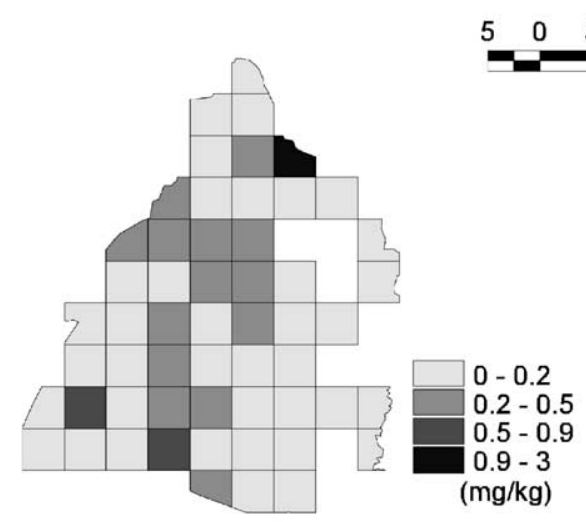

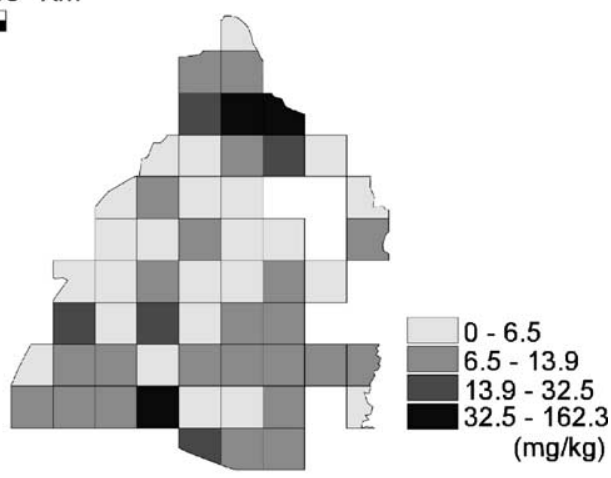

(d)

Fig. 4. Sampling maps of soil heavy metal: (a) As, (b) $\mathrm{Cd}$, (c) $\mathrm{Cr}$, and (d) $\mathrm{Cu}$.

Table 3

Statistics of soil heavy metals

\begin{tabular}{lcccrrrrr}
\hline Metal & $\mathrm{As}$ & $\mathrm{Cd}$ & $\mathrm{Cr}$ & $\mathrm{Cu}$ & $\mathrm{Hg}$ & $\mathrm{Ni}$ & $\mathrm{Pb}$ & $\mathrm{Zn}$ \\
\hline$N$ & 55 & 55 & 55 & 55 & 55 & \multicolumn{1}{c}{55} & 55 & \multicolumn{1}{c}{55} \\
Mean & 5.16 & 0.29 & 4.87 & 14.85 & 0.25 & 8.46 & 8.54 & 27.44 \\
Median & 5.53 & 0.21 & 3.04 & 7.56 & 0.18 & 6.05 & 8.12 & 12.14 \\
Standard deviation & 3.28 & 0.40 & 7.78 & 29.58 & 0.20 & 12.25 & 5.67 & 46.80 \\
Minimum & 0.00 & 0.00 & 0.00 & 0.00 & 0.00 & 0.00 & 0.81 & 0.51 \\
Maximum & 11.76 & 2.99 & 50.71 & 162.33 & 0.84 & 88.91 & 31.23 & 281.75 \\
25th & 2.24 & 0.16 & 1.09 & 3.64 & 0.13 & 3.89 & 4.83 & 8.00 \\
75th & 8.07 & 0.28 & 5.16 & 11.77 & 0.33 & 8.07 & 10.83 & 23.03 \\
\hline
\end{tabular}

Unit: $\mathrm{mg} / \mathrm{kg}$. 


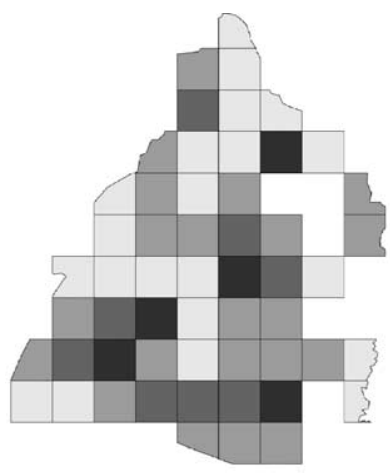

(a)

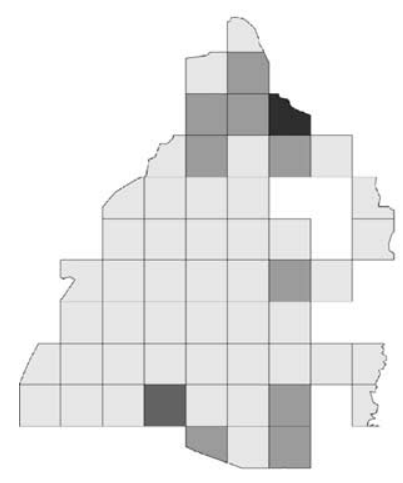

(b)

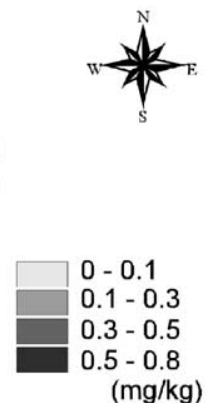

$(\mathrm{mg} / \mathrm{kg})$

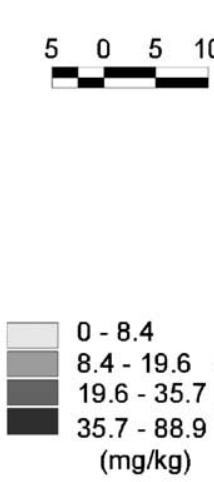

(mg/kg)

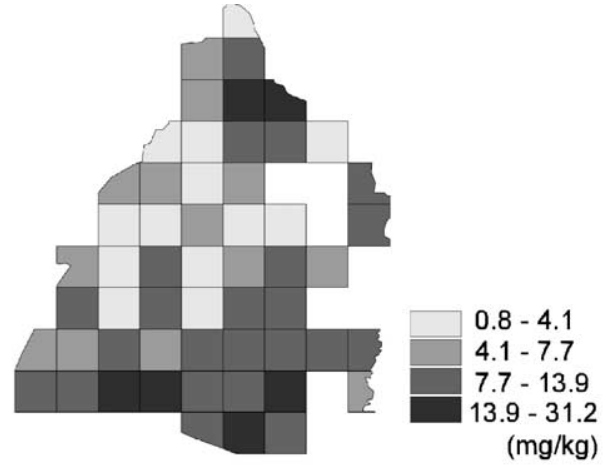

(c)

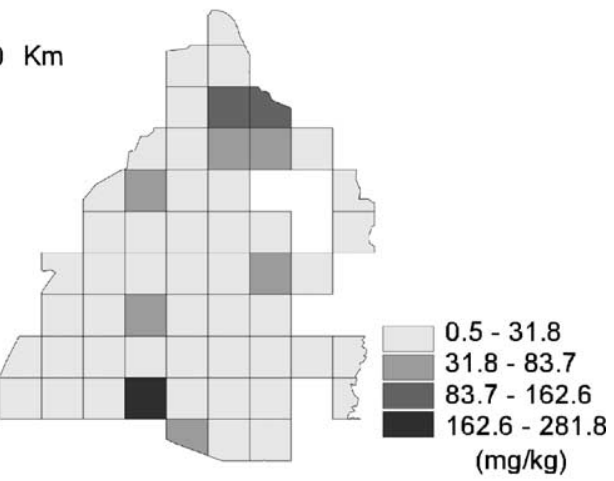

(d)

Fig. 5. Sampling maps of soil heavy metal: (a) $\mathrm{Hg}$, (b) $\mathrm{Ni}$, (c) $\mathrm{Pb}$, and (d) $\mathrm{Zn}$.

display north-south tendency that corresponds to urban planning areas and is parallel to Sun Yet-Sen freeway (Figs. 2 and 6(a)). The values show that the irrigation system covered most of the county (Figs. 3(b) and 6(d)). The higher urban planning area ratios were found in the eastern sampling sites of the study areas (Figs. 3(a) and 6(e)). Most electroplating, textile, metal surface treatment and metal industrial plants were located in the northern sampling sites (Figs. 3(c) and 7). The highly urbanized and industrialized sampling sites were in the east of the study area.

The overlaid map (Fig. 8) of the urban planning area, landscape diversity and industrial plants shows that industrial plants were located at sites with high landscape diversity and a high urban planning area ratio. Most industrial plants were located on the bor- ders of the urban planning area. This finding shows that higher landscape diversity corresponds to a higher urban planning area ratio and more industrial plants.

The results of correlation analysis illustrate that the correlation coefficient between the landscape diversity index $(H)$ and the urban planning area ratio (Raup) is 0.63 , revealing a strong linear correlation at the 0.01 probability level (Table 4). This result confirms that greater man-made landscape diversity corresponds to more urbanization. The correlation coefficients among H, RAup, NE, NT, NMs, NM and Np are significant at the 0.01 probability level, according to the two-tailed test (Table 4). The correlations among $\mathrm{H}$, NMs and NM exceed 0.6. Moreover, RAup is strongly linearly correlated with NE. However, only 


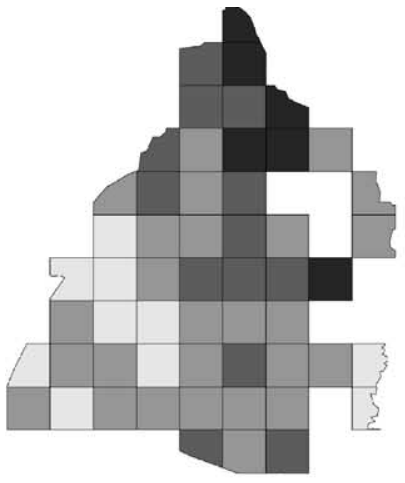

(a)

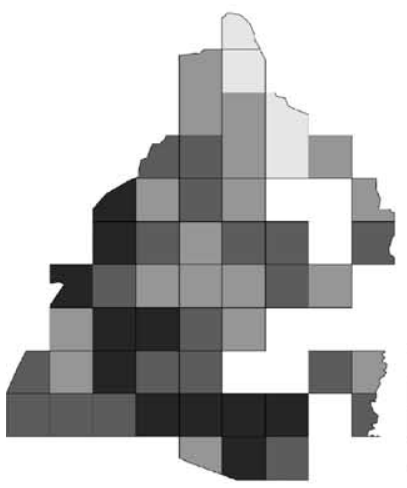

(b)
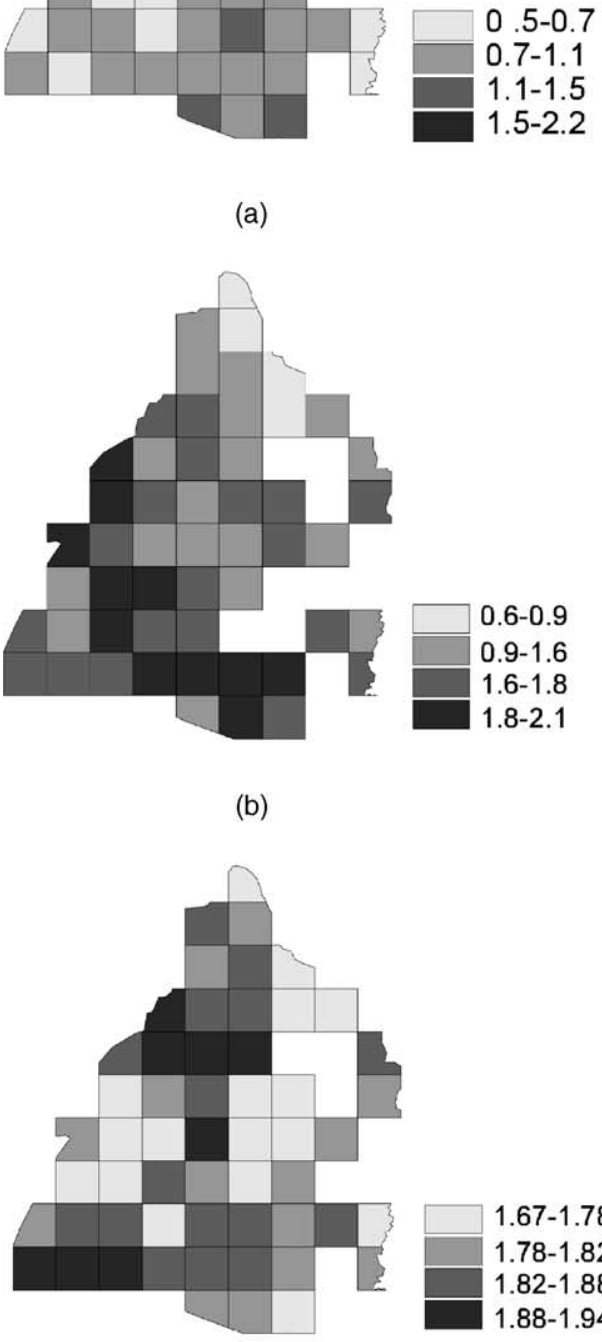

0.6-0.9

$0.9-1.6$

1.6-1.8

1.8-2.1

(c)

$1.67-1.78$

$1.78-1.82$

$1.82-1.88$

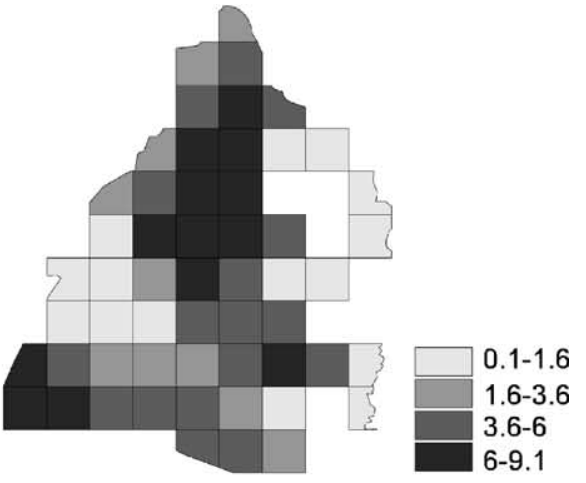

(d)

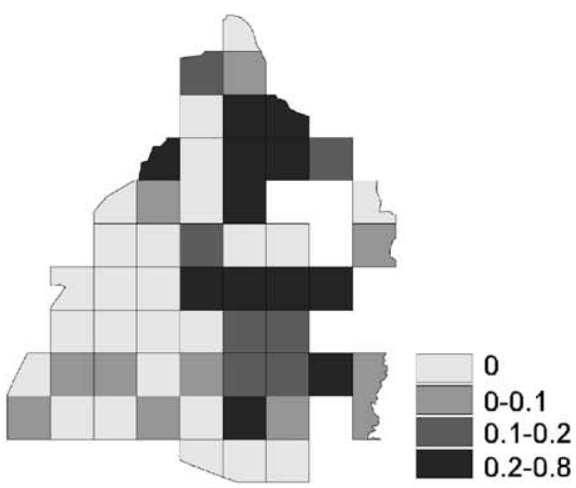

(e)
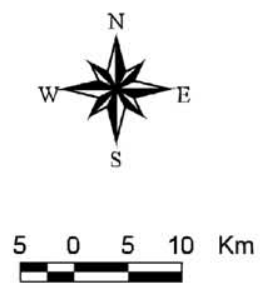

$1.88-1.94$

Fig. 6. Spatial maps of: (a) landscape diversity, (b) landscape dominance, (c) area-perimeter fractal dimension, (d) density of irrigation system, and (e) ratio of urban planning area. 


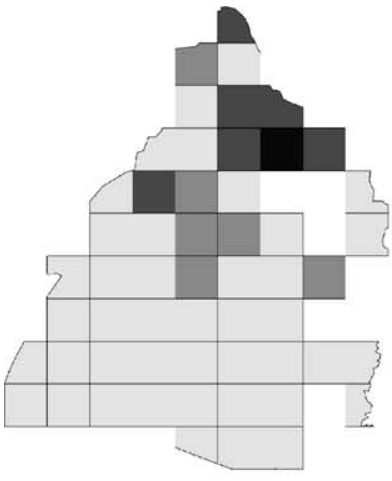

(a)

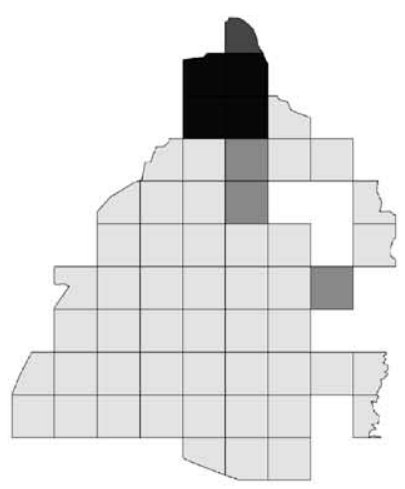

(b)

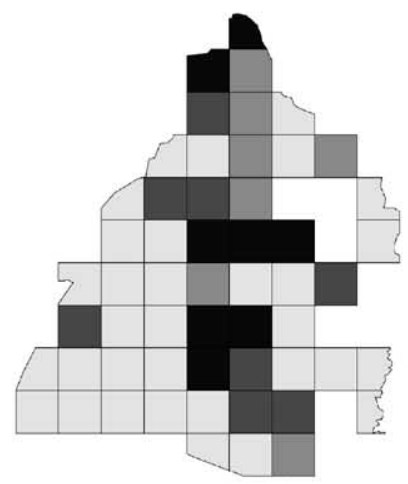

(c)

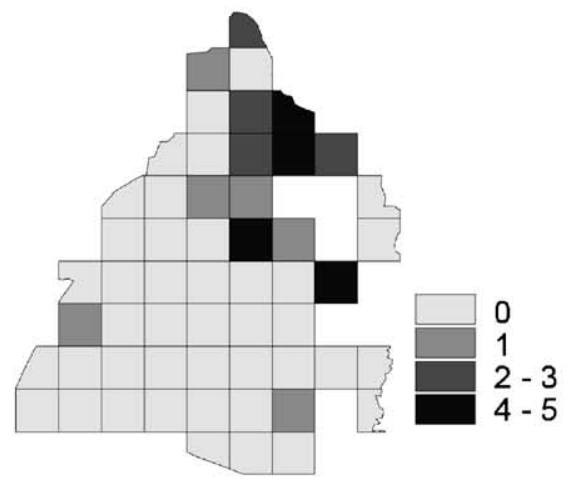

(d)
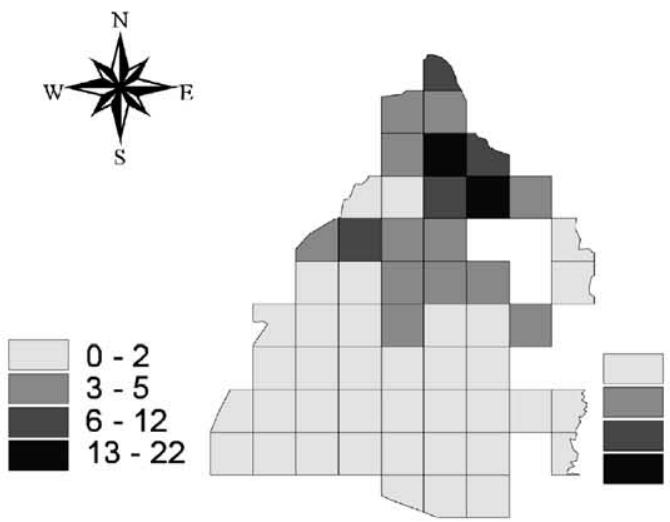

0 - 2

$3-7$

$8-13$

$14-20$

(e)

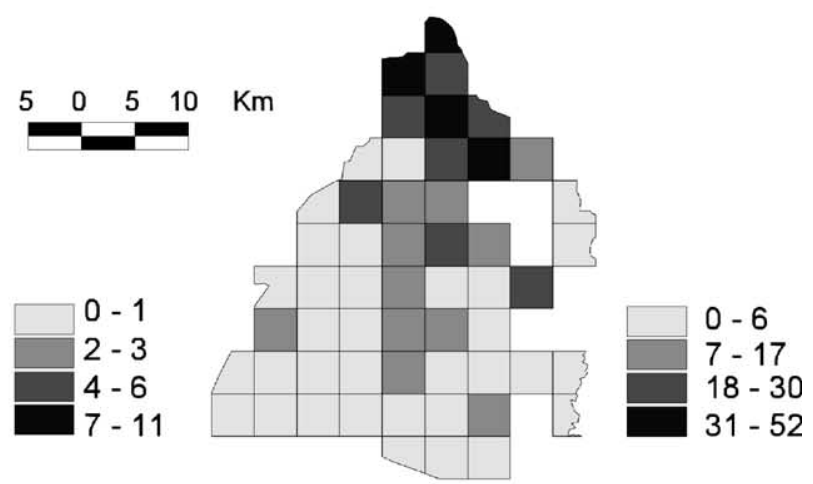

(f)

Fig. 7. Number of: (a) electroplating industrial, (b) textile industrial, (c) livestock industrial, (d) metal surface treatment industrial, (e) metal industrial, and (f) total number of industrial plants at each sampling site. 


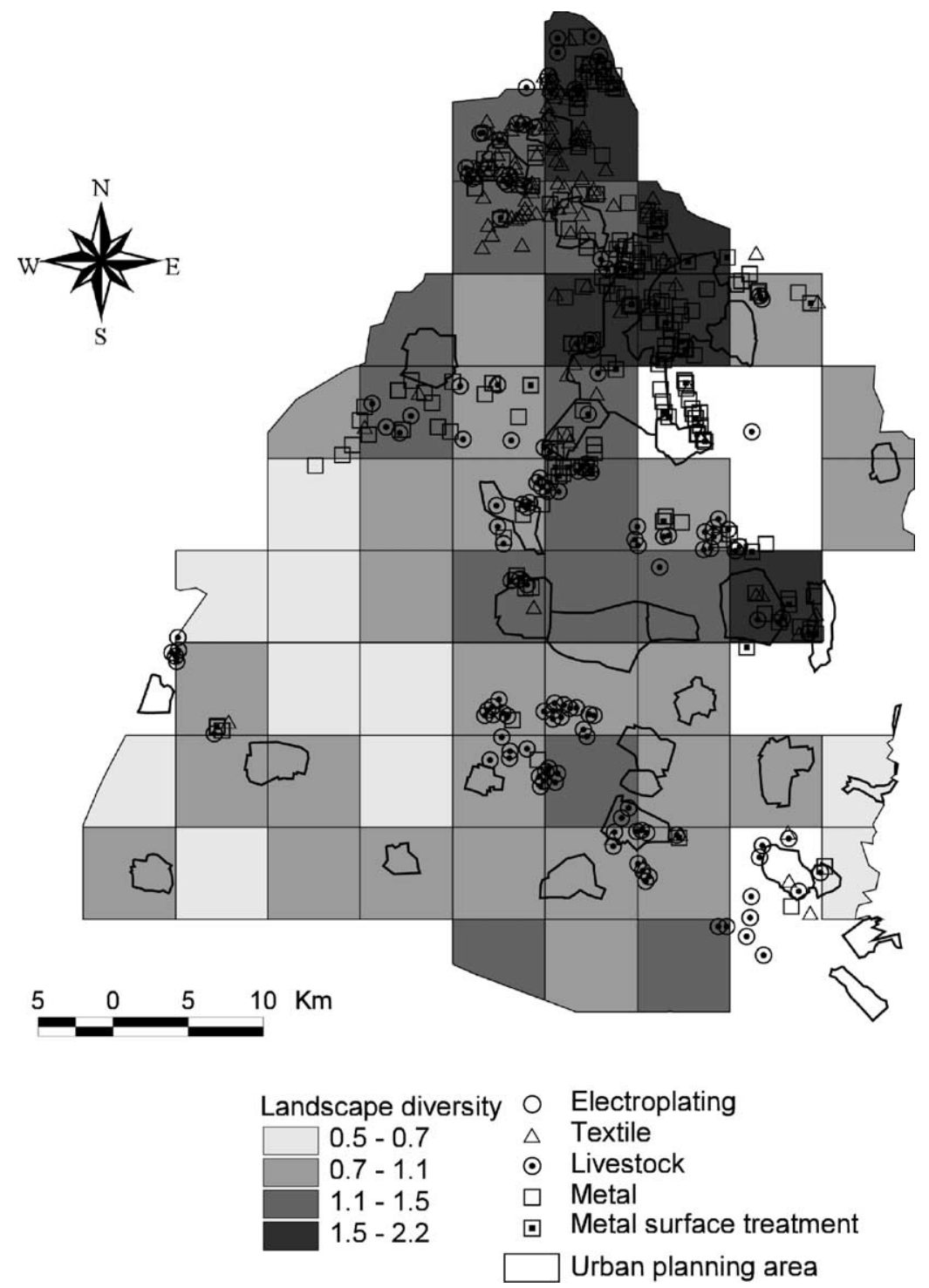

Fig. 8. Overlaying map of landscape diversity, urban planning area and industrial plants.

NL is not significantly correlated with the electroplating plants, metal surface treatment plants and metal plants. The correlations verified results from the overlaying map, which higher urbanization corresponds to higher industrialization (metal industry) across the study area. The landscape spatial pattern and correlation results reflect that industrialization was highly corresponded to urbanization, especially in north and east of Changhua county.

\subsection{Correlation among soil heavy metals and landscape indices}

Pearson correlation coefficients were calculated for 55 pairs of soil heavy metals and landscape indices, to identify relationships among the soil heavy metals and the landscape indices of these 55 sampling sites (Table 5). Cd was significantly correlated $(0.28$ and 0.34 ) with $\mathrm{H}$ and $\mathrm{NE}$ at the 0.05 probability level and 
Table 4

Correlations matrix between landscape indices

\begin{tabular}{lccccccccccc}
\hline & $\mathrm{H}$ & $\mathrm{D}$ & $\mathrm{FD}$ & $\mathrm{DL}$ & $\mathrm{Raup}$ & $\mathrm{NE}$ & $\mathrm{NT}$ & $\mathrm{NL}$ & $\mathrm{NMs}$ & $\mathrm{NM}$ & $\mathrm{Np}$ \\
\hline $\mathrm{H}$ & 1.00 & $-0.74^{* *}$ & 0.02 & 0.12 & $0.63^{* *}$ & $0.67^{* *}$ & $0.42^{* *}$ & 0.22 & $0.61^{* *}$ & $0.72^{* *}$ & $0.71^{* *}$ \\
$\mathrm{D}$ & $-0.74^{* *}$ & 1.00 & 0.19 & 0.02 & $-0.41^{* *}$ & $-0.64^{* *}$ & $-0.42^{* *}$ & -0.08 & $-0.52^{* *}$ & $-0.68^{* *}$ & $-0.065^{* *}$ \\
FD & 0.02 & 0.19 & 1.00 & $0.46^{* *}$ & 0.13 & -0.06 & 0.07 & -0.02 & -0.17 & 0.04 & -0.00 \\
DL & 0.12 & 0.02 & $0.46^{* *}$ & 1.00 & 0.08 & 0.03 & 0.05 & 0.09 & 0.04 & 0.10 & 0.08 \\
Raup & $0.63^{* *}$ & $-0.41^{* *}$ & 0.13 & 0.08 & 1.00 & $0.64^{* *}$ & 0.14 & -0.00 & $0.50^{* *}$ & $0.57^{* *}$ & $0.49^{* *}$ \\
NE & $0.67^{* *}$ & $-0.64^{* *}$ & -0.06 & 0.03 & $0.64^{* *}$ & 1.00 & 0.23 & 0.08 & $0.74^{* *}$ & $0.86^{* *}$ & $0.77^{* *}$ \\
NT & $0.42^{* *}$ & $-0.42^{* *}$ & 0.07 & 0.05 & 0.14 & 0.23 & 1.00 & $0.31^{*}$ & 0.22 & $0.52^{* *}$ & $0.72^{* *}$ \\
NL & 0.22 & -0.077 & -0.02 & 9.09 & -0.00 & 0.08 & $0.31^{*}$ & 1.00 & 0.24 & 0.26 & $0.49^{* *}$ \\
NMs & $0.61^{* *}$ & $-0.52^{* *}$ & -0.17 & 0.04 & $0.50^{* *}$ & $0.74^{* *}$ & 0.22 & 0.24 & 1.00 & $0.72^{* *}$ & $0.69^{* *}$ \\
NM & $0.72^{* *}$ & $-0.68^{* *}$ & 0.04 & 0.10 & $0.57^{* *}$ & $0.86^{* *}$ & $0.52^{* *}$ & 0.26 & $0.72^{* *}$ & 1.00 & $0.92^{* *}$ \\
Np & $0.71^{* *}$ & $-0.65^{* *}$ & -0.01 & 0.08 & $0.49^{* *}$ & $0.77^{* *}$ & $0.72^{* *}$ & $0.49^{* *}$ & $0.69^{* *}$ & $0.92^{* *}$ & 1.00 \\
\hline
\end{tabular}

${ }^{*} P<0.05$ level (two-tailed).

** $P<0.01$ level (two-tailed).

(0.45) with NMs at the 0.01 probability level, according to the two-tailed test. The correlation coefficients of $\mathrm{Cr}$ with landscape indices, $\mathrm{H}$, NE and NMs, are $0.374,0.377$ and 0.448 , respectively, revealing a significant relationship at the 0.01 probability level. $\mathrm{Cu}$ was significantly related to $\mathrm{NE}$ and $\mathrm{NMs}$ at the 0.05 probability level. Landscape indices (H, NE and NMs) were significantly related to $\mathrm{Ni}$, at the 0.01 probability level. $\mathrm{Zn}$ was significantly correlated with $\mathrm{NE}$ and NMs ( 0.28 and 0.29 , respectively) at the 0.05 probability level.

According to our results, the soil heavy metals $\mathrm{Cr}$, $\mathrm{Cd}$ and $\mathrm{Ni}$ were significantly related to the location and number of the electroplating and metal surface treatment industrial plants. The concentrations of these three heavy metals were also significantly correlated with the landscape diversity index. Therefore, higher $\mathrm{Cr}, \mathrm{Cd}$ and $\mathrm{Ni}$ concentrations were associated with greater urbanization and industrialization. Moreover, $\mathrm{Cu}$ was also correlated with the locations of electroplating, metal surface treatment and metal industrial plants. This correlation analysis also reveals that local urbanization and industrialization may have dominated the local characteristics of soil heavy metal pollution in Taiwan's Changhua county, especially in north and east of this study county.

\subsection{Factor analysis of heavy metals and landscape indices}

Factor analysis results revealed that the four-group model explained $94.1 \%$ of the total variation of the

Table 5

Correlations of soil heavy metals with landscape indices

\begin{tabular}{|c|c|c|c|c|c|c|c|c|}
\hline & As & $\mathrm{Cd}$ & $\mathrm{Cr}$ & $\mathrm{Cu}$ & $\mathrm{Hg}$ & $\mathrm{Ni}$ & $\mathrm{Pb}$ & $\mathrm{Zn}$ \\
\hline $\mathrm{H}$ & 0.07 & $0.28^{*}$ & $0.37^{* *}$ & 0.22 & -0.01 & $0.36^{* *}$ & 0.10 & 0.25 \\
\hline $\mathrm{D}$ & -0.01 & $-0.31^{*}$ & $-0.32^{*}$ & -0.12 & 0.20 & $-0.31^{*}$ & 0.03 & -0.10 \\
\hline DL & 0.04 & 0.14 & 0.11 & 0.17 & -0.15 & 0.13 & 0.06 & 0.15 \\
\hline Raup & 0.02 & 0.14 & 0.18 & 0.16 & 0.15 & 0.17 & 0.06 & 0.15 \\
\hline $\mathrm{NE}$ & 0.18 & $0.34^{*}$ & $0.38^{* *}$ & $0.30^{*}$ & 0.06 & $0.39^{* *}$ & 0.10 & $0.28^{*}$ \\
\hline NT & -0.04 & -0.08 & 0.12 & 0.22 & -0.05 & 0.02 & 0.03 & 0.11 \\
\hline NL & 0.15 & -0.15 & -0.14 & -0.10 & -0.04 & -0.13 & -0.21 & -0.13 \\
\hline NMs & 0.24 & $0.45^{* *}$ & $0.45^{* *}$ & $0.31^{*}$ & 0.00 & $0.47^{* *}$ & 0.07 & $0.29^{*}$ \\
\hline NM & 0.15 & 0.15 & 0.25 & $0.30^{*}$ & -0.08 & 0.21 & 0.02 & 0.26 \\
\hline $\mathrm{Np}$ & 0.15 & 0.13 & 0.25 & $0.28^{*}$ & -0.04 & 0.21 & 0.00 & 0.21 \\
\hline
\end{tabular}

\footnotetext{
${ }^{*} P<0.05$ (two-tailed).
}

** $P<0.01$ (two-tailed). 
Table 6

Eigenvalues and amount of variance of four factors

\begin{tabular}{llll}
\hline Factor & Eigenvalue & Variance $(\%)$ & Cumulative $(\%)$ \\
\hline 1 & 2.77 & 34.6 & 34.4 \\
2 & 2.73 & 34.1 & 68.8 \\
3 & 1.01 & 12.7 & 81.4 \\
4 & 1.01 & 12.6 & 94.1 \\
\hline
\end{tabular}

soil heavy metal (As, $\mathrm{Cd}, \mathrm{Cr}, \mathrm{Cu}, \mathrm{Hg}, \mathrm{Pb}$ and $\mathrm{Zn}$ ) data over this study area (Table 6). Table 7 displays the varimax rotated factor scores. Fig. 9 shows the factor loading maps of the 55 sampling sites. The first and second factors explained $68.7 \%$ of the total variation. The first factor, explaining $34.6 \%$ of the total variation, exhibited a high positive factor loading on $\mathrm{Cd}$, $\mathrm{Cr}$ and Ni. The second factor exhibited a high positive factor loading on $\mathrm{Cu}, \mathrm{Pb}$ and $\mathrm{Zn}$. The first and second factors were directly related to electroplating
Table 7

Factor loadings of soil heavy metals

\begin{tabular}{lrlrr}
\hline Factor & \multicolumn{1}{l}{2} & \multicolumn{2}{l}{3} & \multicolumn{1}{l}{4} \\
\hline $\mathrm{As}$ & 0.09 & 0.05 & -0.04 & 0.99 \\
$\mathrm{Cd}$ & 0.97 & 0.15 & -0.02 & 0.10 \\
$\mathrm{Cr}$ & 0.81 & 0.55 & -0.05 & -0.02 \\
$\mathrm{Cu}$ & 0.39 & 0.87 & 0.00 & 0.04 \\
$\mathrm{Hg}$ & -0.04 & 0.11 & 0.99 & -0.04 \\
$\mathrm{Ni}$ & 0.90 & 0.38 & 0.01 & 0.08 \\
$\mathrm{~Pb}$ & 0.12 & 0.89 & 0.16 & 0.04 \\
$\mathrm{Zn}$ & 0.44 & 0.84 & 0.04 & 0.03 \\
\hline
\end{tabular}

and metal treatment industrial plants. The first three factors explained $81.4 \%$ of the total variation of the soil heavy metal data. The third and fourth factors showed a high positive factor loading on $\mathrm{Hg}$ and $\mathrm{As}$, respectively. According to the soil classes defined by EPA (Table 1), As soil concentrations between 4 and $9 \mathrm{mg} / \mathrm{kg}$ are background values in Taiwan. $\mathrm{Hg}$ soil

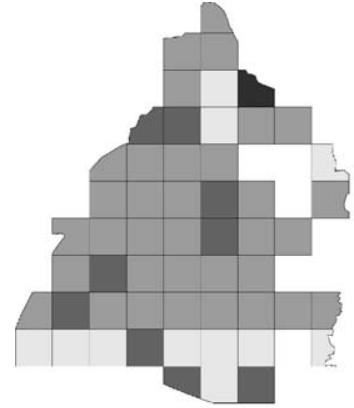

(a)

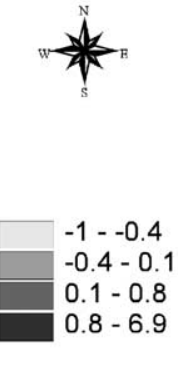

(a)

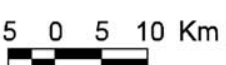

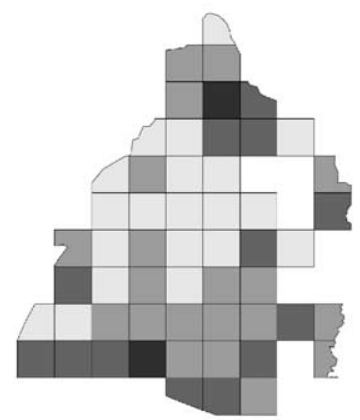

(b)

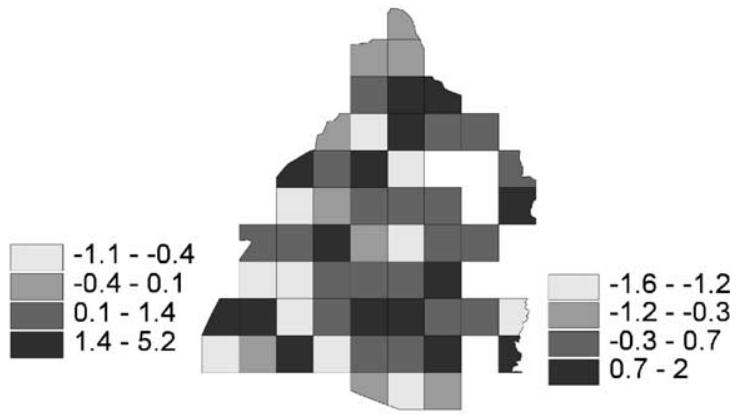

(d)

Fig. 9. Spatial maps of factors loading of: (a) factor 1, (b) factor 2, (c) factor3, and (d) factor 4. 
concentrations between 0.1 and $0.39 \mathrm{mg} / \mathrm{kg}$ are also background values. Accordingly, the mineralogy of the parent material dominates the total As and $\mathrm{Hg}$ content of the soil (Chang et al., 1999).
A six-factor model accounted for $82.0 \%$ of the total variation of the soil heavy metals and landscape indices data (Tables 8 and 9). The first factor explained $34.5 \%$ of the total variation of the soil heavy metals

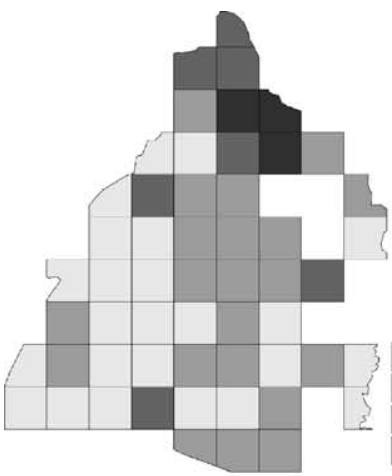

(a)

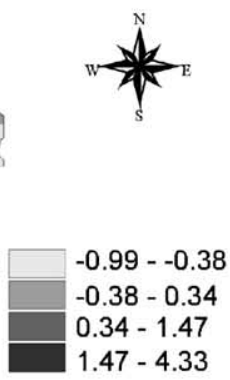

$1.47-4.33$

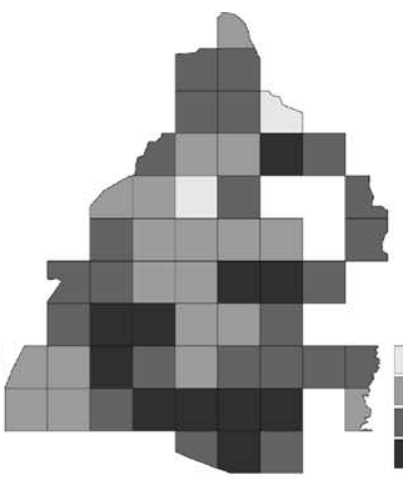

(d)

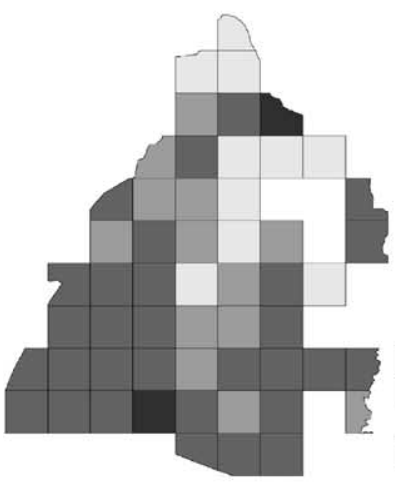

(b)

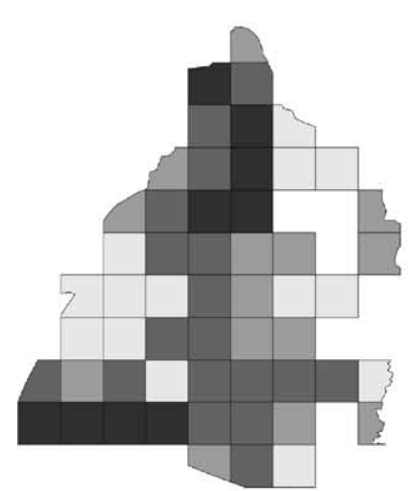

(c)

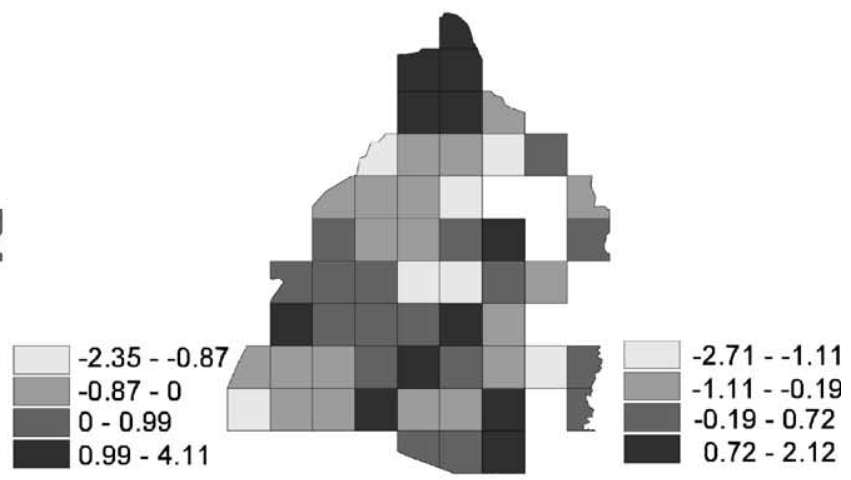

(e)

$1.11--0.19$

$-0.19-0.72$

$0.72-2.12$
$-2.61--2.14$

$-2.14--0.36$

$-0.36-0.68$

$0.68-3.04$
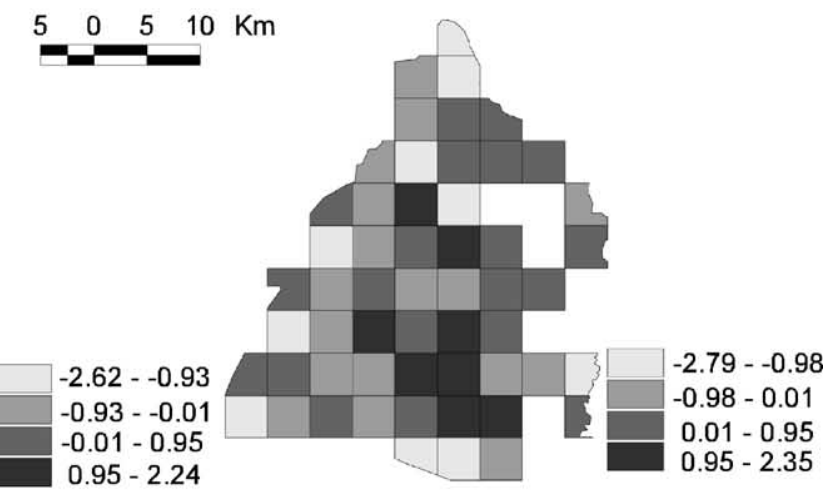

(f)

Fig. 10. Spatial maps of factors loading of (a) factor 1, (b) factor 2, (c) factor3, (d) factor 4, (e) factor 5, and (f) factor 6. 
Table 8

Eignevalues and amount of variance of six factors

\begin{tabular}{llll}
\hline Factor & Eigenvalue & Variance $(\%)$ & Cumulative $(\%)$ \\
\hline 1 & 6.55 & 34.5 & 34.5 \\
2 & 3.56 & 18.7 & 53.2 \\
3 & 1.68 & 8.9 & 62.1 \\
4 & 1.39 & 7.3 & 69.4 \\
5 & 1.27 & 6.7 & 76.0 \\
6 & 1.12 & 5.9 & 82.0 \\
\hline
\end{tabular}

and landscape indices, and had positive factor loadings on $\mathrm{Cd}, \mathrm{Cr}, \mathrm{Cu} \mathrm{Ni}, \mathrm{Zn}, \mathrm{H}$, RAup, NE, NMs, NM and $\mathrm{Np}$ (Table 9). These variables included not only urbanization (H and RAup) and industrialization indices (NE, NMs, NM and NP), but also soil heavy metals ( $\mathrm{Cd}, \mathrm{Cr}$, $\mathrm{Cu}, \mathrm{Ni}$ and $\mathrm{Zn}$ ). The first factor was related to the impact of urbanization and industrialization (metal industry) on soil heavy metals. The second factor explained $18.7 \%$ of the total variation of the variables, and exhibited positive factor loadings on $\mathrm{Pb}$, but moderate factor loadings on $\mathrm{Cd}, \mathrm{Cr}, \mathrm{Cu}, \mathrm{Ni}$ and $\mathrm{Zn}$ (Table 9), perhaps because soil $\mathrm{Pb}$ might not only be dominated by industrial activity, but also controlled by other human activities such as traffic use. The third factor explained $8.9 \%$ of the total variation of variables, and represented patch shapes of landscapes. The fourth and

Table 9

Factor loadings of soil heavy metals and landscape indices

\begin{tabular}{lllrrrr}
\hline Factor & 1 & \multicolumn{1}{l}{2} & \multicolumn{1}{l}{3} & \multicolumn{1}{l}{4} & \multicolumn{1}{l}{5} \\
\hline As & 0.20 & 0.03 & 0.00 & -0.38 & 0.07 & 0.74 \\
Cd & 0.62 & 0.52 & -0.30 & -0.33 & -0.13 & -0.00 \\
Cr & 0.75 & 0.59 & -0.11 & -0.01 & 0.072 & -0.14 \\
Cu & 0.65 & 0.58 & 0.26 & 0.13 & 0.22 & -0.01 \\
Hg & 0.00 & 0.13 & 0.03 & 0.75 & -0.04 & 0.37 \\
Ni & 0.71 & 0.57 & -0.22 & -0.20 & 0.00 & -0.02 \\
Pb & 0.38 & 0.64 & 0.28 & 0.33 & 0.13 & 0.04 \\
Zn & 0.64 & 0.62 & 0.20 & 0.13 & 0.15 & 0.09 \\
H1 & 0.77 & -0.36 & 0.01 & 0.05 & -0.14 & -0.11 \\
D1 & -0.67 & 0.40 & 0.25 & 0.08 & 0.05 & 0.34 \\
FD & -0.03 & 0.03 & 0.80 & -0.10 & -0.36 & 0.01 \\
DL & 0.15 & 0.08 & 0.63 & -0.44 & -0.31 & -0.06 \\
Raup & 0.57 & -0.31 & 0.05 & 0.30 & -0.52 & 0.08 \\
NE & 0.81 & -0.31 & -0.13 & 0.11 & -0.25 & 0.13 \\
NT & 0.42 & -0.40 & 0.33 & 0.09 & 0.51 & -0.31 \\
NL & 0.13 & -0.47 & 0.21 & -0.22 & 0.50 & 0.33 \\
NMs & 0.78 & -0.22 & -0.21 & -0.07 & -0.06 & 0.25 \\
NM & 0.79 & -0.50 & 0.10 & 0.05 & -0.02 & 0.02 \\
Np & 0.78 & -0.55 & 0.15 & 0.03 & 0.23 & 0.03 \\
\hline
\end{tabular}

sixth factors explained 7.3 and $5.9 \%$ of the total variation of variables, respectively, and had high positive factor loading on $\mathrm{Hg}$ and $\mathrm{As}$, perhaps dominated by the mineralogy of the parent material. The fifth factor, representing the textile and livestock industries, explained $6.7 \%$ of the total variation of variables.

Fig. 10 displays all factor loadings maps of the 55 sampling sites. These maps indicated that most sample sites with high first factor loadings were highly correlated to the urban planning areas and distribution of metal industrial plants (Figs. 3(a), (c) and 10(a)). Moreover, the highest factor loading was located in the north of this study area. These patterns of factor loading may show that the soil quality was influenced by industrialization and urbanization, especially in and around urban planning areas. Most high second factor scores were at sampling sites with high $\mathrm{Pb}$ values, in the south of the study area (Fig. 10(b)). Moreover, the patterns of the third factor loadings were highly correlated with the distribution and forms of irrigation systems (Figs. 3(b) and 10(c)). This result reveals that irrigation systems may be governed by land use geometry in the study area. Higher irrigation network density corresponds to more fragmented land use. The fifth factor exhibited high factor loadings around sampling sites with low irrigation density and fragmentation. The high factor loadings of the fourth and sixth factors were randomly distributed across the county (Figs. 10(d) and (f)), which results may be verified by the previous factor analyses of heavy metal data and EPA classifications. Natural factors mainly determine As concentration.

\section{Conclusions}

This study determined landscape patterns and soil heavy metal pollution patterns using landscape indices, multivariate analyses, correlation analysis, and a geographic information system, to establish references for landscape management and to understand the effects of urbanization and industrialization on soil pollution. Landscape indices, landscape diversity, dominance, area-perimeter fractal dimension, density of irrigation ditches, number of electroplating plants, number of textile plants, number of livestock plants, number of metal surface treatment plants and number of metal plants, total number of industrial plants, and 
the ratio of urban planning area to total area, effectively elucidated the spatial patterns of land use, urbanization and industrialization across the study area.

The correlation analysis of soil heavy metals and landscape indices indicated that heavy metal pollution of soil was dominated by local human activity and urban and industrial land uses in Changhua county in Taiwan. Factorial analysis can classify soil heavy metals and landscape indices into a six-factor model to identify soil pollution in relation to landscape patterns and human activities in Changhua county. Finally, a Geographic information system can comprehensively display the spatial patterns and relationships among of landscape indices and soil heavy metals in the study area.

\section{References}

Aguiar, M.R., Sala, O.E., 1999. Patch structure, dynamics and implications for the functioning of arid ecosystems. Trends Ecol. Evol. 14 (7), 273-277.

Bastian, O., Roder, M., 1998. Assessment of landscape change by land evaluation of past and present situation. Landscape Urban Plan. 4, 171-182.

Baudry, J., Burel, F., Thenail, C., Le Cúur, D., 2000. A holistic landscape ecological study of the interactions between farming activities and ecological patterns in Brittany, France. Landscape Urban Plan. 50, 119-128.

Brejda, J.J., 1998. Factor-analysis of nutrient distribution patterns under shrub live-oak in two contrasting soils. Soil Sci. Soc. Am. J. 62 (3), 805-809.

Briz-Kishore, B.H., Murali, G., 1992. Factor analysis for revealing hydrochemical characteristics of a watershed. Environ. Geol. 19, 3-9.

Burgess, R.L., Sharpe, D.M., 1981. Forest Island Dynamics in Man Dominated Landscape. Springer, New York.

Carlon, C., Critto, A., Marcomini, A., Nathanail, P., 2001. Risk based characterization of contaminated industrial site using multivariate and geostatistical tools. Environ. Pollut. 111, 417427.

Chang, T.K., Shyu, G.S., Lin, Y.P., Chang, N.C., 1999. Geostatistical analysis of soil arsenic content in Taiwan. J. Environ. Sci. Health A 34 (7), 1485-1501.

Forman, R.T.T., 1995. Land Mosaics: The Ecology of Landscapes and Regions. Cambridge University Press, Cambridge, UK.

Forman, R.T.T., Godron, M., 1986. Landscape Ecology. Wiley, New York.

Fu, B.J., Chen, L.D., 2000. Agricultural landscape spatial pattern analysis in the semiarid hill area of the loess plateau, China. J. Arid Environ. 44 (3), 291-303.

Haines-Young, R., Chopping, M., 1996. Quantifying landscape structure-a review of landscape indices and their application to forest landscape. Process Phys. Geogr. 20 (4), 418-445.
Haycock, N.E., Muscutt, A.D., 1995. Landscape management strategies for the control of diffuse pollution. Landscape Urban Plan. 31, 313-321.

Hietala-Koivu, R., 1999. Agricultural landscape change: a case study in YlaÈne, southwest Finland. Landscape Urban Plan. 46, 103-108.

Hokit, D.G., Smith, B.M., Branch, L.C., 1999. Effect of landscape structure in Florida scrub-a population perspective. Ecol. Appl. 9 (1), 124-134.

Hulshoff, R.M., 1995. Landscape indices describing a Dutch landscape. Landscape Ecol. 10 (2), 101-111.

Jayakumar, R., Siraz, L., 1997. Factor analysis in hydrogeochemistry of coastal aquifers-a preliminary study. Environ. Geol. 31 (3/4), 174-177.

Johnson, L.B., Gage, S.H., 1997. Landscape approaches to the analysis of aquatic ecosystems. Freshwater Biol. 37, 113-132.

Kienast, F., 1993. Analysis of historic landscape patterns with a geographical information system-a methodological outline. Landscape Ecol. 8 (2), 103-118.

Klenner, W., Kurz, W., Beukema, S., 2000. Habitat patterns in forested landscapes: management practices and the uncertainty associated with natural disturbances. Comput. Electron. Agric. 27, 243-262.

Krummel, J.R., Gardner, R.H., Sugihara, G., O’Neill, R.V., Coleman, P.R., 1987. Landscape patterns in a disturbed environment. Oikos 48, 321-324.

Leduc, A., Prairie, Y., Bergeron, Y., 1994. Fractal dimension estimates of a fragmented landscape: sources of variability. Landscape Ecol. 9 (4), 279-286.

Lewis-Beck, M.S., 1994. Factor Analysis and Related Techniques. SAGE Inc., Jurong, Singapore.

Li, B.L., Archer, S., 1997. Weighted mean patch size-a robust index for quantifying landscape structure. Ecol. Model. $102(2 / 3), 353-361$.

Lin, Y.P., Chang, T.K., 2000a. Geostatistical simulation and estimation of the spatial variability of soil zinc. J. Environ. Sci. Health, Part A Toxic/Hazardous Substance Environ. Eng. A 35 (3), 327-347.

Lin, Y.P., Chang, T.K., 2000b. Simulated annealing and kriging method for identifying the spatial patterns and variability of soil heavy metal. J. Environ. Sci. Health, Part A Toxic/Hazardous Substance Environ. Eng. A 35 (7), 1089-1115.

Lin, Y.P., Chang, T.K., Teng, T.P., 2001. Characterization soil lead comparing sequential Gaussian simulation, simulated annealing simulation and kriging methods. Environ. Geol. 41 (1/2), 189199.

Meng, A.K., Suffet, I.H., 1997. A procedure for correlation of chemical and sensory data in drinking-water samples by principal component factor-analysis. Environ. Sci. Technol. 31 (2), 345-377.

Nikora, V.I., Pearson, C.P., Shankar, U., 1999. Scaling properties in landscape patterns: New Zealand experience. Landscape Ecol. 14, 17-33.

Norusis, M.J., 1993. SPSS for Windows Base System User's Guide Release 6.0, SPSS Inc.

O'Neill, R.V., Krummel, J.R., Gardner, R.H., Sugihara, G., Jackson, B., DeAngeles, D.L., Milne, B.T., Turner, M.G., 
Zygmunt, B., Christensen, S.W., Dale, V.H., Graham, R.L., 1988. Indices of landscape pattern. Landscape Ecol. 1 (2), 153162.

Obeysekera, J., Rutchey, K., 1997. Selection of scale for everglades landscape models. Landscape Ecol. 12 (1), 7-18.

Stadler, P.F., 1999. Fitness landscapes arising from the sequence-structure maps of biopolymers. J. Mol. Struct. (Theochem) 463, 7-19.

Subbarao, C., Subbarao, N.V., Chandu, S.N., 1996. Characterization of groundwater contamination using factor analysis. Environ. Geol. 28 (4), 175-180.
Turner, M.G., 1987. Spatial simulation of landscape changes in Georgia: a comparison of three transition models. Landscape Ecol. 1, 29-36.

Turner, M.G., 1990. Landscape changes in nine rural counties in Georgia,. Photogram. Eng. Remote Sens. 56 (3), 379386.

Urban, D.L., O’Neill, R.V., Shugart, H.H., 1987. Landscape ecology. Bioscience 37, 119-127.

Weinstoerffer, J., Girardin, P., 2000. Assessment of the contribution of land use pattern and intensity to landscape quality: use of a landscape indicator. Ecol. Model. 130, 95-109. 